\title{
U.S. Competition Policy and the Free Market Philosophy: A Moral Justification
}

Citation for published version (APA):

Bos, I. (2019). U.S. Competition Policy and the Free Market Philosophy: A Moral Justification. Maastricht University, Graduate School of Business and Economics. GSBE Research Memoranda No. 003 https://doi.org/10.26481/umagsb.2019003

Document status and date:

Published: 28/01/2019

DOI:

10.26481/umagsb.2019003

Document Version:

Publisher's PDF, also known as Version of record

\section{Please check the document version of this publication:}

- A submitted manuscript is the version of the article upon submission and before peer-review. There can be important differences between the submitted version and the official published version of record.

People interested in the research are advised to contact the author for the final version of the publication, or visit the DOI to the publisher's website.

- The final author version and the galley proof are versions of the publication after peer review.

- The final published version features the final layout of the paper including the volume, issue and page numbers.

Link to publication

\footnotetext{
General rights rights.

- You may freely distribute the URL identifying the publication in the public portal. please follow below link for the End User Agreement:

www.umlib.nl/taverne-license

Take down policy

If you believe that this document breaches copyright please contact us at:

repository@maastrichtuniversity.nl

providing details and we will investigate your claim.
}

Copyright and moral rights for the publications made accessible in the public portal are retained by the authors and/or other copyright owners and it is a condition of accessing publications that users recognise and abide by the legal requirements associated with these

- Users may download and print one copy of any publication from the public portal for the purpose of private study or research.

- You may not further distribute the material or use it for any profit-making activity or commercial gain

If the publication is distributed under the terms of Article $25 \mathrm{fa}$ of the Dutch Copyright Act, indicated by the "Taverne" license above, 


\section{Maastricht University}

Iwan Bos

U.S. Competition Policy and the Free Market Philosophy: A Moral Justification

RM/19/003

\section{GSBE}

Maastricht University School of Business and Economics

Graduate School of Business and Economics

P.O Box 616

NL-6200 MD Maastricht

The Netherlands 


\section{U.S. Competition Policy and the Free Market Philosophy:}

\section{A Moral Justification ${ }^{1}$}

by

Iwan Bos ${ }^{2}$

(January 2019)

"Keep on Rockin' in the Free World!" (Neil Young, 1989)

\section{Introduction}

The year 1776 AD witnessed two landmark events in the history of the Free World. In the United Kingdom of Great Britain, a book by Scottish scholar Adam Smith (1723-1790) was published entitled An Inquiry into the Nature and Causes of the Wealth of Nations. A main takeaway of this manuscript is that a decentralized free market system in which individuals solely pursue their self-interest may be more beneficial than a centralized system in which a few decide for the many. On the other side of the Atlantic, enemies of this Kingdom announced the Declaration of Independence, which marked the birth of the United States of America. Ever since the start, the free market philosophy such as set out in the Wealth of Nations has been part of this country's DNA.

\footnotetext{
${ }^{1}$ I acknowledge the valuable comments of Ivan Boldyrev, Johan Graafland and Eelke de Jong. This paper is written as part of the research project What Good Markets Are Good For and made possible through the support of a grant from Templeton World Charity Foundation, Inc.. The opinions expressed in this publication are mine alone and do not necessarily reflect the views of Templeton World Charity Foundation, Inc..

${ }^{2}$ Department of Organization \& Strategy, School of Business and Economics, Maastricht University. E-mail: i.bos@maastrichtuniversity.nl.
} 
In spite of the widespread believe in the merits of the free market, it did not take long before U.S. legislators limited market participants' freedom through the adoption of antitrust laws. First at the state level and since the late $1800 \mathrm{~s}$ at the federal level, these rules of competition intended to combat particular business practices such as price-fixing and monopolizing conduct. After a somewhat hesitant start, competition policy quickly became a key factor in all kind of business transactions. The first national U.S. antitrust law (i.e., the Sherman Act) was even perceived as having near-constitutional status at some point. Chief Justice Hughes, for instance, wrote that: ${ }^{3}$

"As a charter of freedom, the [Sherman] Act has a generality and adaptability comparable to that found to be desirable in constitutional provisions."

And in the early 1970 s, the U.S. Supreme Court stated: ${ }^{4}$

"Antitrust laws in general and the Sherman Act in particular, are the Magna Carta of free enterprise. They are as important to the preservation of economic freedom and our free enterprise system as the Bill of Rights is to the protection of our fundamental personal freedoms. And the freedom guaranteed each and every business, no matter how small, is the freedom to compete -- to assert with vigor, imagination, devotion, and ingenuity whatever economic muscle it can muster."

Without questioning the impact and importance of competition policy, there is something inherently paradoxical about its presence in a free-market based society like the U.S.. After all, the free market tradition as it evolved through Scottish Enlightenment and British nineteenth century liberalism essentially identifies a trade-off between government and market. Simply put, more market means less government and vice versa. Proponents of

\footnotetext{
${ }^{3}$ Appalachian Coals, Inc. v. U.S., 288 U.S. 344 (1933).

${ }^{4}$ U.S. v. Topco Assocs., Inc., 405 U.S. 596 (1972).
} 
this philosophy generally favour the market and advocate a laissez-faire policy. Yet, the development of U.S. competition policy unquestionably led to more government intervention and, although celebrated by many as an expression of freedom, therefore seems at odds with the free market philosophy. ${ }^{5}$

The thesis of this paper is that competition policy is compatible with the free market philosophy, but only to the extent that it is essential for free market existence. More rather than less government intervention may be warranted when the free market would effectively disappear absent competition law enforcement. In that case, government and market are no longer communicating vessels; less government might no longer imply more market, but rather no market (in the sense proper) at all.

There are basically two ways in which U.S. competition policy stimulates free market survival. First, it aims to preserve the free market institution by shaping market structure. Among other things, this includes lowering entry barriers and merger policy. Second, it aims to promote the free market spirit by enhancing the equality of opportunity. In particular, it supports small entrepreneurs and incentivizes businessmen to beat the competition by offering superior value propositions rather than through employing wasteful anticompetitive measures. Both make American competition policy consistent with the free market philosophy and consequently provide a moral justification for its presence.

In the next section, we briefly describe the historical context within which U.S. competition policy emerged. Section 3 offers a rough overview of this policy and shows how it slowly but surely expanded. The main argument of how competition law enforcement fits within the free market tradition is developed in detail in Section 4 and Section 5. Section 6 concludes.

\footnotetext{
${ }^{5}$ It is noteworthy that some free market scholars have defended competition law enforcement by comparing it to more intrusive forms of government intervention such as regulation and ownership.
} 


\section{Historical Context}

Let us begin by briefly sketching the historical context within which American competition policy emerged. The body of antitrust laws did not just fall from the sky. Rather, there were significant economic, social and political developments in the second half of the $19^{\text {th }}$ century that formed a fertile soil for its creation. At the heart of it was the rise of big business, which was increasingly frowned upon, debated and even feared by economists, legislators and the American people.

Around $1800 \mathrm{AD}$, the U.S. were already clearly developing as a nation. Market competition was, however, still mainly local and among small suppliers. Manufacturers typically controlled no more than $10 \%$ of their industry's production, for example. ${ }^{6}$ Markets tend to work reasonably efficient in such an environment, because neither buyers nor suppliers possess the power to upset the price mechanism. It was the absence of two vital ingredients that prevented producers from growing into bigger enterprises. The first was monetary means to invest in large quantities of input to produce large quantities of output. The second was a significant level of demand for the product to make such an investment worthwhile. Both became increasingly available throughout the $19^{\text {th }}$ century, which in turn enabled the rise of some of the most iconic American corporations (e.g., Standard Oil, General Motors, American Telephone \& Telegraph).

Regarding the first ingredient, substantial expansion investments came within reach primarily through the separation of ownership and control. At the time, it was common for owners to run their own business. And even though this ensures extensive control on daily operations, it also limits investment opportunities. By giving up (part of) the ownership through the issuing of stocks, monetary means could be generated in a relatively short

\footnotetext{
${ }^{6}$ See Heilbroner and Milberg (2002, p. 87).
} 
period. In turn, this made it possible to set-up large production facilities. But, what good is large-scale production when there are not enough customers to purchase the output?

This brings us to the second ingredient, which became available primarily through the development of infrastructure. Both communication devices and means of transportation improved with an unprecedented speed. In 1844, for instance, Samuel Morse succeeded in connecting Baltimore and Washington by telegraph. Just a few years later, cables linked New York to New Orleans and Chicago. Postal services developed in a similar fashion. Whereas U.S. Postal Service mainly used horses and coach to transport mail around 1830, railways were developing westward and quickly became a superior substitute. Flows of production were further facilitated through a network of waterways. Already in 1825 , the famous Erie Canal became functional and many more canals were built in the ensuing decades. Together, these developments led to a rapid and substantial growth of markets as well as of some of the suppliers who now started to operate on a national scale.

Next to this expansion of markets, there was growing social and political unrest. Not long after the ending of the Civil War (1861-1865), Americans witnessed the advent of what became known as the Long Depression. This period of downturn is considered to have started with the Great Panic of 1873; a financial crisis that led to strikes and economic instability. The resulting downward drop in demand provided the newborn corporations with a strong and natural incentive to reduce their prices. A more profitable alternative to such a cutthroat strategy, however, was to restrict or even eliminate market competition. And this is precisely what happened. Indeed, the U.S. saw a rise in horizontal price-fixing agreements and large-scale mergers unequalled in its young history. ${ }^{7}$

\footnotetext{
${ }^{7}$ It should be noted that there was quite some variety in the way in which industries transformed into centres of business power, including monopolization, cartels, pools and trusts. First introduced in the oil industry, a
} 
Railroad companies, for instance, coordinated their actions to drive up prices. ${ }^{8}$ Perhaps the most telling example was the Standard Oil trust established by John D. Rockefeller, which the $27^{\text {th }}$ U.S. president, William Howard Taft, once described as: ${ }^{9}$

"...the greatest monopoly and combination in restraint of trade in the world,...an octopus that held the trade in its tentacles, and the few actual independent concerns that kept alive were allowed to exist by sufferance merely to maintain an appearance of competition..."

One consequence of these anti-competitive business practices was that a substantial amount of wealth ended up in the hand of a few. This, in turn, fuelled public opinion against the fast emergence of big business and trusts. These anti-bigness sentiments combined with the fear for concentrations of market power was at the heart of the development of the first antitrust laws. Towards the end of the $19^{\text {th }}$ century, many considered the significant consolidation of industry and the emergence of powerful business combinations a severe threat. ${ }^{10}$ In fact, some politicians vividly argued that this perceived danger could not be ignored. Indeed, it was Senator John Sherman from Ohio who stated that: ${ }^{11}$

"You must heed their [the voters] appeal or be ready for the socialist, communist, and the nihilist,"

thereby paving the way for U.S. competition policy.

\footnotetext{
trust was a (at the time) legal form of business organization where participants gave up control over their companies in exchange for a fixed share of profits generated by the trust.

${ }^{8}$ The emergence of powerful trusts was widespread. As Heilbroner and Milberg $(2002$, p. 86) state: "It was not just the railroad industry that used economic power to create a monopoly position. In whiskey and sugar, in tobacco and cattle feed, in wire nails, steel hoops, electrical appliances, tinplate, in matches and meat, there was an octopus similar...".

${ }^{9}$ Taft, the Anti-Trust Acts and the Supreme Court (1914), cited in Orbach and Sokol (2013).

${ }^{10}$ George Gunton, a known defender of trusts at the time, stated that the situation was "surcharged with an indefinite but almost inexpressible fear of trusts." See Stocking and Watkins (1951).

${ }^{11}$ See Thorelli (1955).
} 


\section{U.S. Competition Policy}

Though certainly not the first collection of competition rules in history, competition law enforcement is widely acknowledged to have been born with the passage of Bill S. I in the U.S. on July 2, $1890 .{ }^{12}$ Today, this bill is known as the Sherman Act, named after Senator Sherman who proposed it at the $51^{\text {st }}$ Congress and who at the time appeared one of the most articulate spokespersons on the subject. Together with the Clayton Act and the Federal Trade Commission (FTC) Act of 1914, this law still forms the foundation of today's U.S. federal competition policy.

The Sherman Act has two substantive sections:

Section 1: Every contract, combination in the form of trust or otherwise, or conspiracy, in restraint of trade or commerce among the several States, or with foreign nations, is declared to be illegal. Every person who shall make any contract or engage in any combination or conspiracy hereby declared to be illegal shall be deemed guilty of a felony...

Section 2: Every person who shall monopolize, or attempt to monopolize, or combine or conspire with any other person or persons, to monopolize any part of the trade or commerce among the several States, or with foreign nations, shall be deemed guilty of a felony...

As noted by many, the wording in both provisions is fairly vague and flexible. Consequently, the actual meaning of concepts like "conspiracy", "restraint of trade" and "(attempt to) monopolize" had to be determined in concrete court cases. ${ }^{13}$

\footnotetext{
${ }^{12}$ Quite a few states already adopted competition laws prior to 1890 as did Canada in 1889 . See, for example, Stigler (1985).

${ }^{13}$ Not surprisingly, the broad formulation also laid the basis for extensive discussions about the (intended) goals of antitrust. Some scholars have advocated that the sole intent was to maximize allocative efficiency (e.g., Bork (1978)). The more popular view is that Congress and courts aimed at promoting a combination of values, including the protection of small businesses and consumers (e.g., Schwartz (1979), Lande (1982) and Stigler (1985)).
} 
In their search for sound judicial interpretations, some judges turned to common law from the pre-Sherman Act period. ${ }^{14}$ Although no directly comparable common law principles existed, useful elements could be found in ancient private and criminal doctrines. Cases concerning restraints of trade were, for instance, commonly dealt with under contract law. Interestingly, several of these cases already revealed clear anti-monopoly sentiments as the next quote illustrates. ${ }^{15}$

"The clear tendency of such an agreement is to establish a monopoly, and to destroy competition in trade, and for that reason, on grounds of public policy, courts will not aid in its enforcement."

In fact, this statement reflects the overall common law stance on anticompetitive combinations such as cartels; they were typically tolerated, but not legally enforceable.

During the decades after the passage of the Sherman Act, legal discussions mainly revolved around the question whether challenged business practices should be subject to a reasonableness test or be declared illegal per se. Under a rule-of-reason standard, the court balances adverse and beneficial effects of a particular business act in order to judge its legality. It was this approach that was explicitly embraced as the standard in two cases in 1911. ${ }^{16}$ However, it did not take long before the Supreme Court established a per se prohibition for fixing prices. ${ }^{17}$ Over time, the scope of the per se rule has widened and an increasing number of business practices (e.g., market division, customer allocation, group boycotts) are held illegal independent of their actual effect on the market.

\footnotetext{
${ }^{14}$ Hylton (2003) provides an extensive discussion of the relation between the antitrust acts and the common law.

${ }^{15}$ Central Ohio Salt Co. v. Guthrie, 35 Ohio St. 666 (1880). For similar examples, see Thorelli (1955) and Kintner (1980).

${ }^{16}$ These cases are: Standard Oil Co. of New Jersey v. U.S. 221 U.S. 1 (1911) and U.S. v. American Tobacco Co., 221 U.S. 106 (1911).

${ }^{17}$ This happened primarily through two case decisions: U.S. v. Trenton Potteries Company et al. 273 U.S. 392 (1927) and U.S. v. Socony-Vacuum Oil Co. et al., 310 U.S. 150 (1940).
} 
Pleas by defendants and prominent economists on the potential beneficial effects of combinations increasingly fell on deaf ears, therefore. Cartels, for example, were recurrently referred to as "children of distress" that ensured order and stability, particularly during economic downturns. ${ }^{18}$ The central argument was that in the presence of high fixed and low variable costs, excess production capacity would trigger ruinous competition resulting in bankruptcies and unemployment. Cartels were considered a natural way out of such slumps. Not long after the Great Depression of the 1930s, however, the Supreme Court reconfirmed the per se approach towards price-fixing by reasoning that: ${ }^{19}$

"Ruinous competition, financial disaster, evils of price-cutting, and the like appear throughout our history as ostensible justifications for price-fixing. If the so-called competitive abuses were to be appraised here, the reasonableness of prices would necessarily become an issue in every pricefixing case. In that event, the Sherman Act would soon be emasculated; its philosophy would be supplanted by one which is wholly alien to a system of free competition; it would not be the charter of freedom which its framers intended."

Apart from these developments in the courtroom, two companion laws were enacted in 1914; the Clayton Act and the FTC Act. The Clayton Act prohibits a number of specific business practices such as price discrimination, tying and exclusive dealing contracts. Moreover, its Section 7 prohibits mergers to the extent that its effect would be to substantially lessen competition. The key provision of the FTC Act, Section 5, declares unlawful unfair methods of competition.

\footnotetext{
${ }^{18}$ Kleinwächter (2017) coined the phrase "Kartelle sind Kinder der Not" ("Cartels are Children of Distress") as far back as 1883. A general discussion on cutthroat competition can be found in Scherer (1980, pp. 212-216). ${ }^{19}$ U.S. v. Socony-Vacuum Oil Co. et al., 310 U.S. 150 (1940).
} 
Similar to the Sherman Act, however, these laws were not very effective at first. Congress attempted to address this problem through the adoption of various amendments in the ensuing decades. It, for example, passed the Robinson-Patman Act in 1936. This law substantially amended the Clayton Act by making it applicable to a wider class of business situations and by enhancing enforcement possibilities. In particular, this act aimed to protect small businesses by countering the advantageous market position of big enterprises somewhat. Large firms can, for example, often buy their inputs in bulk and negotiate a quantity discount. As such discounts are typically not available to small buyers, this type of price discrimination might have the effect to substantially lessen competition and thus be prohibited.

With the passage of the Clayton Act and the FTC Act, U.S. competition law enforcement changed from a primarily reactive to a more proactive policy; a trend fuelled by several amendments like the Robinson-Patman Act throughout the $20^{\text {th }}$ century. This point can be illustrated with an example on merger policy.

In principle, a merger could be challenged under Section 2 of the Sherman Act in case it violated some monopolization standard. Section 7 of the Clayton Act went a significant step further by installing an incipiency standard. It intended to "arrest the creation of trusts, conspiracies and monopolies in their incipiency and before consummation". ${ }^{20}$ Hence, it enabled antitrust intervention at a point where potential harmful effects of the merger were not yet manifest. Congress went yet another step further with the enactment of the Hart-Scott-Rodino Antitrust Improvements Act in 1976. Among other things, this set of amendments contains premerger notification provisions. Prior to a merger (or acquisition), parties involved are required to file a notification with the Federal Trade Commission and

\footnotetext{
${ }^{20}$ Senate Report 698, 15.657, 63rd Cong., second session, 1914, p.1. The Celler-Kefauver Act of 1950 strengthened the incipiency standard and broadened the scope of the Clayton Act by making it applicable to asset acquisition cases and mergers between firms that are no direct competitors. A detailed description can be found in Scherer (1980).
} 
the U.S. Department of Justice. These agencies then scrutinize the proposed transaction and assess its potential (anti-)competitive effects. Depending on the findings, the proposed merger may then be approved or challenged instead.

During the past few decades, the most prominent changes took place in enforcement policy and the courtroom. An amnesty program has been installed, for instance, which induces firms involved in competition law violations to self-report in exchange for a reduction of the antitrust penalty. The role of economic analysis in competition cases has grown substantially and facilitated in the development of this program as well as in the estimation of antitrust damages. This arguably led to a more severe enforcement of U.S. competition laws, both in terms of total corporate fines collected and years of imprisonment. ${ }^{21}$

\section{Preservation of the Free Market Institution}

The above description of U.S. competition policy development sketches a picture of (directly and indirectly) increasing government intervention. Anticompetitive agreements between firms were often tolerated under $19^{\text {th }}$ century common law, but generally not legally enforceable. This ended with the passage of the Sherman Act, which made illegal particular monopolizing business practices. A few decades later, its companion laws introduced an incipiency standard and declared unlawful unfair methods of competition. Further restrictions on market transactions were imposed throughout the $20^{\text {th }}$ century and merger policy became tighter overall. ${ }^{22}$

\footnotetext{
${ }^{21}$ A detailed empirical analysis and discussion of recent trends in U.S. competition law enforcement is provided by Ghosal and Sokol (2014).

22 It should be noted that this trend was non-monotonic. For example, merger control became temporarily less strict under the presidency of Ronald Reagan in the 1980s as it was viewed an unnecessary form of government intervention.
} 
This expanding set of restraints seems fundamentally at odds with the freemarket philosophy. Not only did it limit the liberty of market participants, but it also led to a larger rather than a smaller government. As we will argue in the following, however, competition policy is compatible with the free market tradition if one considers it a prerequisite for the preservation of the free market institution.

To begin, let us clarify what we mean when we qualify the market as free. It is clear that one can approach this issue in many ways, but we believe the following simple perspective is sufficient to facilitate the discussion. Imagine a remote village with a single representative market place where merchants offer their products to potential buyers. When would we consider such a market to be (non-)free? The following stylized figure sheds light on this question.

\begin{tabular}{|l|l|l|}
\hline Supply Barriers & Low \\
\hline High & Non-Free & Demand Free \\
\hline Low & Supply Free & Free \\
\hline
\end{tabular}

Figure 1: Stylized Model of a (Non-)Free Market Definition.

A market is a, potentially abstract, place where buyers and sellers interact and Figure 1 combines this in one particular fashion. The rows represent the supply side and the columns capture the demand side. Starting with 
the supply side, a distinction is made between high and low entry barriers. These barriers are considered high when it is prohibitively costly for newcomers with a competitive value proposition to enter the market. They are considered low when these potential entrants find it profitable to access this market through setting-up their own stands. The demand side in some sense mirrors the supply side perspective by distinguishing between high and low exit barriers. Exit barriers are considered high when actual buyers lack a reasonable alternative, which may be reflected by a low demand elasticity and a high willingness to pay. Instead, these barriers are low when buyers face attractive outside options.

This approach identifies four possible scenarios. One case is when both entry and exit barriers are low. This is characteristic of a free market. In this situation, entrepreneurs do not encounter unnatural barriers when pursuing new business opportunities in this market. Likewise, customers face no difficulties in leaving this market when confronted with suboptimal value propositions. A market can also be semi-free. It is supply free when entry barriers are low and buyers lack attractive outside options. ${ }^{23}$ If the opposite holds, then the market is demand free. The market is non-free when both barriers are high. Firms willing to enter such a market face severe obstacles, whereas consumers have no reasonable alternative.

It is clear that actual markets may vary in their degree of entry and exit barriers and therefore in the extent to which they are supply or demand free. Moreover, one should bear in mind that both entry and exit barriers may be in part endogenous. Markets that are initially free might through time transform into semi-free or non-free ones. If a few free-market firms become dominant, for instance, they may successfully adopt lobbying

\footnotetext{
${ }^{23}$ Blake and Jones (1965, pp. 383-384) explicitly formulate the desirability of supply free markets as follows: "The individual who wants to be an entrepreneur rather than an employee ought not to have his opportunities restricted by unnecessary barriers to entry, or by trade practices designed specifically to eliminate him from the field."
} 
tactics or entry deterring strategies. ${ }^{24}$ Similarly, exit barriers may be raised over time. Buyers might, for example, experience switching costs after getting used to existing products. Also, they may sign long-term contracts that strongly attach them to incumbent suppliers.

In terms of concentrations of economic power and market performance, however, there is no reason to consider free and semi-free markets problematic. After all, under such market conditions supra-competitive profits cannot be sustained for long. In supply free markets, for example, above normal industry performance would attract newcomers, which in turn would create a downward pressure on prices and profits. In demand free markets, incumbents are naturally constrained by the attractive outside options of their customers. This too precludes excessive profits and abuse. This is not to say that market performance will be poor in non-free concentrated markets. In fact, it is well-known that perfectly competitive outcomes may emerge even in isolated price-setting duopolies. ${ }^{25} \mathrm{High}$ entry and exit barriers are therefore a necessary, but not a sufficient condition for high market power and poor market performance.

If even non-free markets may de facto function as free ones, then how can we reconcile the presence of competition policy with the free market philosophy? One answer lies in the fear that absent rules of competition the free market would effectively disappear. This fear is understandable when two conditions hold. First, it must be considered likely that non-free markets emerge on a large scale. It is noteworthy that this fear was reflected recurrently in U.S. antitrust history. For example, in 1889 Senator Jones and Turpie respectively stated that: ${ }^{26}$

\footnotetext{
${ }^{24}$ Concentrations of power were indeed not only thought to threaten individual well-being, but also the political process. See, for instance, Millon (1988) who writes on balance of power in relation to the Sherman Act and states that: "Economic power meant political power because wealth provided the means to create dependence and thereby collect political influence."

${ }^{25}$ This result is, however, commonly referred to as the Bertrand paradox, see Tirole (1988).

${ }^{26}$ See 20 Cong. Record 1457 and 21 Cong. Record 137. Bold emphasis is ours.
} 
"...These commercial monsters called trusts...[are] preying upon every industry, and by their unholy combinations robbing their victims, the general public..."

And

"...The conspirators of the trust...are hunting the prey, dividing the spoil in every market..."

Second, non-free markets must be viewed as breeding grounds for enduring concentrations of power, which in turn would severely limit the freedom of (a substantial part of) businesses and consumers. This belief was also widespread. In fact, it was John Sherman himself who once formulated it as follows: ${ }^{27}$

"...If the concentered powers of this combination are intrusted to a single man, it is a kingly prerogative, inconsistent with our form of government, and should be subject to the strong resistance of the State and national authorities. If anything is wrong this is wrong. If we will not endure a king as a political power we should not endure a king over the production, transportation, and sale of any of the necessaries of life. If we would not submit to an emperor we should not submit to an autocrat of trade, with power to prevent competition and to fix the price of any commodity..."

And in the famous Alcoa antitrust case, Judge Hand referred to another observation by Sherman: ${ }^{28}$

"...The popular mind is agitated with problems that may disturb social order, and among them all none is more threatening than the inequality of condition, of wealth, and opportunity that has grown within a single generation out of the concentration of capital into vast combinations to control production and trade and to break down competition. These combinations already defy or control powerful transportation corporations and reach State authorities. They reach out their Briarean arms to every part of our country. They are imported from abroad. Congress alone can deal with them, and if we are unwilling or unable there will soon be a trust for every production and a master to fix the price for every necessity of life..."

\footnotetext{
27 See 21 Cong. Record 2457.

${ }^{28}$ See United States v. Aluminum Co. of America, 148 F.2d 416 (2d Cir. 1945).
} 
Of course, this is not to say that these expressed fears were justified. Although market concentration was increasing rapidly in many industries, one might argue that even after the rise of the corporation most markets were still (semi-) free in the sense defined above. ${ }^{29}$ Rather, the point is that the presence of competition law enforcement is compatible with a free market system if one considers it essential to its existence.

\section{Promotion of the Free Market Spirit}

The approach of U.S. competition policy to preserve the free market institution has been to prohibit particular anticompetitive business practices and to shape industry structures (e.g., through merger policy). This, one may argue, is its direct effect; the creation of a context within which individuals and firms are free to pursue their own best interests. Yet, these competition rules arguably not only affect the stage on which the game is played, but also the players themselves. In particular, they not just face protection from anticompetitive measures by rivals, but are simultaneously incentivized to behave more competitively. It is this indirect effect of U.S. competition policy that we now turn to.

There are at least two ways through which U.S. competition policy stimulates the free market spirit. The first is due to the idea that freedom requires balance of power. More specifically, one of the main merits of a decentralized market system is that none has the power to dominate others. This, in turn, is considered to safeguard freedom for all. The free market philosophy is thus in some sense more about equality than about freedom; it is the equality of condition and opportunity that is thought to

\footnotetext{
${ }^{29}$ In reflecting on the American industry composition in the second half of the $19^{\text {th }}$ century, Stigler (1985) remarks: "The average business is not capable of achieving effective cartelization or monopoly, simply because the small relative size of an efficient enterprise and the absence of entry barriers make such goals unattainable."
} 
ensure freedom for American citizens and undertakings. ${ }^{30}$ And it is precisely this equality that was threatened by the emergence of the giant corporations and trusts.

It is then not surprising that the rise of oligarchs as well as a dominant managerial class was met with great suspicion. ${ }^{31}$ There was (and, in fact, still is) strong sympathy for the small business owner who attempts to make a living through hard work and dedication. This widespread sympathy is also reflected in U.S. competition policy. For instance, Judge Hand once reasoned that: 32

"Be that as it may, that was not the way that Congress chose; it did not condone "good trusts" and condemn "bad" ones; it forbad all. Moreover, in so doing it was not necessarily actuated by economic motives alone. It is possible, because of its indirect social or moral effect, to prefer a system of small producers, each dependent for his success upon his own skill and character, to one in which the great mass of those engaged must accept the direction of a few. These considerations, which we have suggested only as possible purposes of the [Sherman] Act, we think the decisions prove to have been in fact its purposes."

One major risk of a severely unbalanced allocation of economic power is that those who find themselves with a lack of it may be discouraged to compete and challenge the establishment. The significant increase of market concentration in many industries was indeed thought to deprive ambitious Americans of the opportunity for prosperity. ${ }^{33}$ One of Congress'

\footnotetext{
${ }^{30}$ As Alexis de Tocqueville stated in his Democracy in America: "I think that democratic communities have a natural taste for freedom; left to themselves, they will seek it, cherish it and view any privation of it with regret. But for equality their passion is ardent, insatiable, incessant, invincible; they call for equality in freedom..."

${ }^{31}$ As observed by Lande (1982): "Decisionmaking was transferred from traditional power centers to the great industrialists. Self-reliant farmers, business owners, and local leaders became dependent on the discretionary power of a few very rich men. Local control of society ended as numerous small power centers were swept away by the new class, one perceived as greedy and evil."

${ }^{32}$ U.S. vs. Aluminum Co. of America, 148 F.2d 416 (2d Cir. 1945). In the same case, it is stated that:

"Throughout the history of these statutes [the antitrust laws] it has been constantly assumed that one of their purposes was to perpetuate and preserve, for its own sake and in spite of possible cost, an organization in small units which can effectively compete with each other."

${ }^{33}$ See, for example, Millon (1988).
} 
goals was therefore to restore the balance of power somewhat and to encourage small businesses by establishing a playground on which they have a fair chance of success. ${ }^{34}$

This is not to say that anything goes within the boundaries of U.S. competition policy, however. In fact, one of the prime benefits of maintaining a free competitive order is considered to be its presumed disciplinary value. Within such a setting, rewards come to those who seek and grasp the opportunities given to them. To be effective in such an environment then requires a certain character. Hofstadter formulated this as follows: ${ }^{35}$

"America was thought to have been made possible by the particular type of character that was forged by competitive individualism, a type that had flourished in the United States because competitive opportunities had been so widespread that alert men could hardly fail to see them, to grasp and use them, and hence, to be shaped by them."

The merits of a decentralized free market system were frequently argued to surpass mere economic considerations. A competitive order in which each is offered a fair chance of prosperity imposes discipline and incentivizes all to embrace those values consistent with a free market economy. Small entrepreneurs who constantly seek to improve their situation are thought to stimulate "expression of the fundamental virtues of thrift, industry, intelligence, schooling, home ties, and family pride". ${ }^{36}$

In turn, these values enable free-market based societies to flourish as a whole. For example, to reap the gains from trade requires men to sufficiently control their emotions and passions. A working free market system can therefore be argued to contribute to a safe society. ${ }^{37}$ Moreover,

\footnotetext{
${ }^{34}$ See Lande (1982).

${ }^{35}$ Hofstadter (1965).

${ }^{36}$ The Small Business Committee of the Senate, cited in Bunzel (1962).

${ }^{37}$ The French scholar Charles Montesquieu is claimed to have said: "... it is almost a general rule that wherever the ways of man are gentle (moeurs douces), there is commerce; and wherever there is commerce, there the ways of man are gentle," and "Commerce... polishes and softens (adoucit) barbarian ways as we can see every day..." See Hirschman (1977).
} 
since one is considered primarily responsible for one's self and relatives, there is a strong sense of community building. Indeed, absent a paternalistic government, individuals quite naturally rely on those around them and who find themselves in a similar position. ${ }^{38}$ This creates mutual sympathy and social stability provided that everyone is given a fair chance to get ahead. The latter imposes a limit on inequality. In particular, losers in the free market should not lose too much as that is likely to create social costs as reflected by limited education and increasing crime rates. ${ }^{39}$

U.S. competition policy can thus be said to enhance the free market spirit in two ways. On the one hand, it offers small business owners a carrot by striving for a sufficiently balanced and fair playground. That is, a selfreliant, hard-working and efficient businessman should have a fair chance of reaping the fruits of his efforts. On the other hand, by protecting and stimulating the competitive process, it provides a stick to discipline all industry members. To be effective within a free market environment, hard work and efficiency are arguably less of a choice and more of a necessity. Indeed, a competitive market mechanism is ultimately the strictest taskmaster of all so that: 40

"Economic freedom is more illusory than it appears. You may do as you please, but if you please to do that which the market disapproves, the price of freedom is ruin."

\footnotetext{
${ }^{38}$ For the U.S., this is described in detail by De Tocqueville (1998).

${ }^{39}$ For a detailed discussion, see Baker and Salop (2015) and the references therein.

${ }^{40}$ See Heilbroner (2000) and Heilbroner and Milberg (2002).
} 


\section{Concluding Remarks}

Few today would doubt the need for competition rules in a free, markedbased society like the United States of America. From a free market philosophy perspective, however, there is something inherently paradoxical about the presence of competition policy. After all, the competition laws that are intended to combat restraints of trade are, in fact, themselves restraints of trade. In this paper, we have argued that competition policy is compatible with the free market philosophy if the free market system would effectively disappear without it and shown that this possibility was considered real in the history of U.S. competition law enforcement.

At the heart is the idea that freedom is best preserved when no one is in the position to dominate others. Taking this perspective, the emergence of trusts and large corporations implied a reduction of freedom for both American citizens and firms. This freedom is, in the words of John Stuart Mill, "that of pursuing our own good in our own way, so long as we do not attempt to deprive others of theirs or impede their efforts to obtain it". ${ }^{41} \mathrm{~A}$ free market rationale for U.S. competition policy is that those with market power cannot be trusted to abide by this principle.

${ }^{41}$ Mill (2003). 


\section{References}

Baker, Jonathan B. and Steven C. Salop (2015), "Antitrust, Competition Policy, and Inequality," Georgetown law Journal, 104(1), 1-28;

Blake, H. and K. Jones (1965), "The Goals of Antitrust: A Dialogue on Policy," Columbia Law Review, 65(3), 377-400;

Bork, R.H. (1978), "The Antitrust Paradox: Policy at War with Itself," Basic Books, New York;

Bunzel, J.H. (1962), "The American Small Businessman," Alfred A. Knopf, New York;

De Tocqueville, A. (1998), "Democracy in America," Wordsworth Classics of World Literature, London;

Ghosal, Vivek and Daniel D. Sokol (2014), "The Evolution of U.S. Cartel Enforcement," Journal of Law and Economics, 57(3), 51-65;

Heilbroner, R.L. (2000), "The Worldly Philosophers: The Lives, Times and Ideas of the Great Economic Thinkers," (revised $7^{\text {th }}$ edition), Penguin Books, London;

Heilbroner, R.L. and W. Milberg (2002), "The Making of Economic Society," $11^{\text {th }}$ edition, Prentice Hall, Upper Saddle River, New Jersey;

Hirschman, Albert O. (1977), "The Passions and the Interests: Political Arguments for Capitalism before its Triumph," Princeton University Press, New Jersey;

Hylton, K.N. (2003), "Antitrust Law: Economic Theory \& Common Law Evolution," Cambridge University Press, Cambridge;

Kitner, E.W. (1980), "Federal Antitrust Law, Volume 1: Economic Theory, Common Law, and the Introduction of the Sherman Act," Cincinnati: Anderson Publishing Co.;

Kleinwächter, F. (2017), "Die Kartelle. Ein Beitrag zur Frage der Organisation der Volkswirtschaft," London: Forgotten Books;

Lande, R.H. (1982), "Wealth Transfers as the Original and Primary Concern of Antitrust: The Efficiency Interpretation Challenged," Hastings Law Journal, 34, 65-151;

Mill, J.S. (2003), "On Liberty," Yale University Press, New Haven; 
Millon, D.K. (1988), "The Sherman Act and the Balance of Power," Southern California Law Review, 61, 1219-1292;

Orbach, B. and D.D. Sokol (2013), "Symposium: 100 years of Standard Oil: Antitrust Energy," Southern California Law Review, 85(3), 429-450;

Scherer, F.M. (1980), "Industrial market structure and economic performance," $2^{\text {nd }}$ edition, Houghton Mifflin Company, Boston;

Schwarz, L.B. (1979), "Justice and other non-economic goals of antitrust," University of Pennsylvania Law Review, 127, 1076-1081;

Smith, A. (1977), "An Inquiry into the Nature and Causes of the Wealth of Nations," Edwin Cannan (ed.), University of Chicago Press, Chicago;

Stigler, G.J. (1985), "The Origin of the Sherman Act," Journal of Legal Studies, 14, 1-12;

Stocking, G.W. and M.W. Watkins (1951), "Monopoly and Free Enterprise," The Twentieth Century Fund, New York;

Thorelli, H.B. (1955), "The Federal Antitrust Policy: Origin of an American Tradition," Johns Hopkins University Press, Baltimore;

Tirole, J. (1988), "The Theory of Industrial Organization," MIT Press, Cambridge, MA.

\section{Law Cases}

Central Ohio Salt Co. v. Guthrie, 35 Ohio St. 666 (1880);

Standard Oil Co. of New Jersey v. U.S., 221 U.S. 1 (1911);

U.S. v. American Tobacco Co., 221 U.S. 106 (1911);

U.S. v. Trenton Potteries Company et al. 273 U.S. 392 (1927);

Appalachian Coals, Inc. v. U.S., 288 U.S. 344 (1933);

U.S. v. Socony-Vacuum Oil Co. et al., 310 U.S. 150 (1940);

U.S. v. Aluminum Co. of America, 148 F.2d 416 (2d Cir. 1945);

U.S. v. Topco Assocs., Inc., 405 U.S. 596 (1972). 